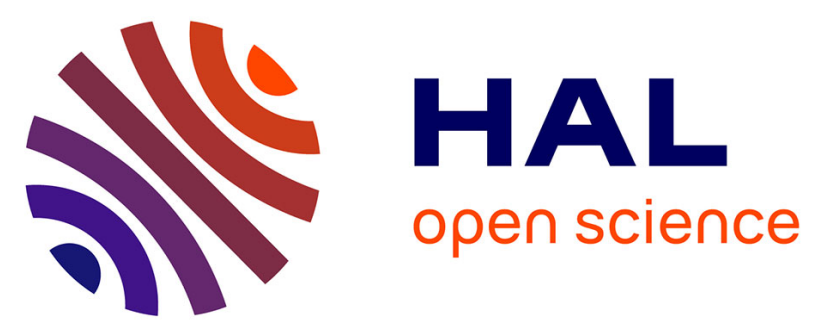

\title{
Design and Synthesis of a 4-Nitrobromobenzene Derivative Bearing an Ethylene Glycol Tetraacetic Acid Unit for a New Generation of Caged Calcium Compounds with Two-Photon Absorption Properties in the Near-IR Region and Their Application in Vivo
}

Satish Jakkampudi, Manabu Abe, Naomitsu Komori, Ryukichi Tagaki, Ko Furukawa, Claudine Katan, Wakako Sawada, Noriko Takahashi, Haruo Kasai

\section{- To cite this version:}

Satish Jakkampudi,, Manabu Abe, Naomitsu Komori, Ryukichi Tagaki, Ko Furukawa, et al.. Design and Synthesis of a 4-Nitrobromobenzene Derivative Bearing an Ethylene Glycol Tetraacetic Acid Unit for a New Generation of Caged Calcium Compounds with Two-Photon Absorption Properties in the Near-IR Region and Their Application in Vivo. ACS Omega, 2016, 1 (2), pp.193-201. 10.1021/acsomega.6b00119 . hal-01395864

HAL Id: hal-01395864

https://hal-univ-rennes1.archives-ouvertes.fr/hal-01395864

Submitted on 12 Nov 2016

HAL is a multi-disciplinary open access archive for the deposit and dissemination of scientific research documents, whether they are published or not. The documents may come from teaching and research institutions in France or abroad, or from public or private research centers.
L'archive ouverte pluridisciplinaire $\mathbf{H A L}$, est destinée au dépôt et à la diffusion de documents scientifiques de niveau recherche, publiés ou non, émanant des établissements d'enseignement et de recherche français ou étrangers, des laboratoires publics ou privés. 


\title{
Design and Synthesis of a 4-Nitrobromobenzene Derivative Bearing an Ethylene Glycol Tetraacetic Acid Unit for a New Generation of Caged Calcium Compounds with Two-Photon Absorption Properties in the Near-IR Region and Their Application in Vivo
}

\author{
Satish Jakkampudi, ${ }^{\dagger \neq}$ Manabu Abe, ${ }^{*}{ }^{\dagger, \ddagger}$ Naomitsu Komori, ${ }^{\dagger}$ Ryukichi Takagi, ${ }^{\dagger}$ Ko Furukawa, ${ }^{\S}$ \\ Claudine Katan, " Wakako Sawada, ${ }^{\perp}$ Noriko Takahashi, ${ }^{\perp}$ and Haruo Kasai ${ }^{* \neq \neq}, \perp$ \\ ${ }^{\dagger}$ Department of Chemistry \& Research Center for Future Science, Graduate School of Science, Hiroshima University, 1-3-1 \\ Kagamiyama, Higashi-Hiroshima, Hiroshima 739-8526, Japan \\ ‡JST-CREST, K’s Gobancho 7, Gobancho, Chiyodaku, Tokyo 102-0075, Japan \\ ${ }^{\S}$ Center for Instrumental Analysis, Institute for Research Promotion, Niigata University, 8050 Ikarashi 2-no-cho, Nishi-ku, Niigata \\ 950-2181, Japan \\ "Institut des Sciences Chimiques de Rennes, UMR 6226 CNRS-Université Rennes 1, 35042 Rennes, France \\ ${ }^{\perp}$ Laboratory of Structural Physiology, CDBIM, Graduate School of Medicine, The University of Tokyo, Bunkyo-ku, Tokyo 113-0033, \\ Japan
}

Supporting Information

ABSTRACT: Among biologically active compounds, calcium ions $\left(\mathrm{Ca}^{2+}\right)$ are one of the most important species in cell physiological functions. Development of new calcium chelators with two-photon absorption (TPA) properties is a state-of-the-art challenge for chemists. In this study, we report the first and efficient synthesis of 5-bromo-2-nitrobenzyl-substituted ethylene glycol tetraacetic acid (EGTA) as a platform for a new generation of calcium chelators with TPA properties in the near-infrared region. New calcium chelators with high TPA properties, that is, a two-photon (TP) fragmentation efficiency of $\delta_{\mathrm{u}}=20.7 \mathrm{GM}$ at $740 \mathrm{~nm}$ for 2-(4nitrophenyl)benzofuran (NPBF)-substituted EGTA (NPBF-EGTA, $\left.K_{\mathrm{d}}=272 \mathrm{nM}\right)$ and $\delta_{\mathrm{u}}=7.8 \mathrm{GM}$ at $800 \mathrm{~nm}$ for 4-amino-4' ${ }^{\prime}$-nitro-1, $1^{\prime}$ biphenyl (BP)-substituted EGTA (BP-EGTA, $K_{\mathrm{d}}=440 \mathrm{nM}$ ) derivatives, were synthesized using Suzuki-Miyaura coupling reactions of the bromide with benzofuran-2-boronic acid and 4-(dimethylamino)phenyl boronic acid, respectively. The corresponding acetoxymethyl (AM) esters were prepared and successfully applied to the $\mathrm{Ca}^{2+}$-uncaging reaction triggered by $\mathrm{TP}$ photolysis in vivo.

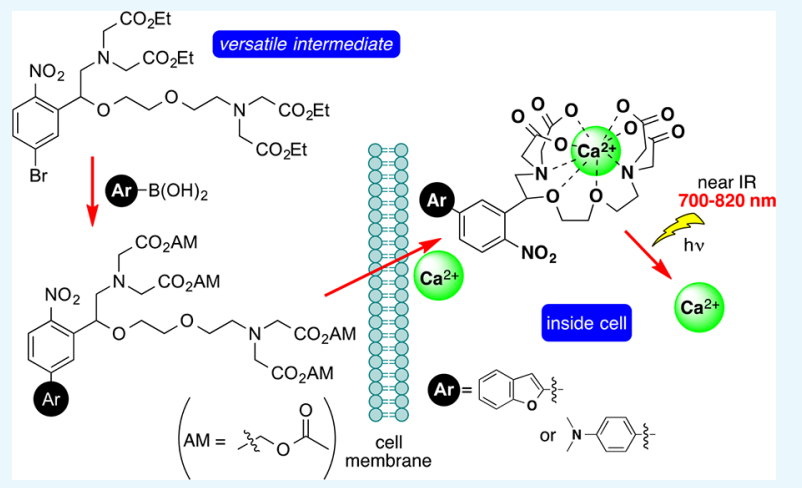

\section{INTRODUCTION}

Calcium ions $\left(\mathrm{Ca}^{2+}\right)$ play pivotal roles in various biological phenomena, ${ }^{1-3}$ including sending and receiving nerve motions, muscle contractions, delivery of hormones and other chemicals such as neurotransmitters, maintaining a normal heartbeat, and blood clotting. Artificial control of $\mathrm{Ca}^{2+}$ levels, $\left[\mathrm{Ca}^{2+}\right]$, in cells would be key to elucidating the role of $\mathrm{Ca}^{2+}$ in biological phenomena. $\mathrm{Ca}^{2+}$ levels may be controlled by the "encapsulation (=caging) and release (=uncaging)" of $\mathrm{Ca}^{2+}$. Biologically active cations $\left(\mathrm{Ca}^{2+}\right)$ can be caged by organic chelators ${ }^{4-9}$ and uncaged by photo-triggered structural changes in the chelator.

Since 1980, the structures of ethylene glycol tetraacetic acid $(\text { EGTA })^{5}$ and 1,2-bis (o-aminophenoxy) ethane- $N, N, N^{\prime}, N^{\prime}$-tetraacetic acid (BAPTA) ${ }^{10,11}$ have been known as excellent chelators that bind selectively to $\mathrm{Ca}^{2+}$ (Figure 1). Indeed, EllisDavies and co-workers used an EGTA chelator for the photochemical uncaging of biologically active $\mathrm{Ca}^{2+} \cdot{ }^{4-9}$ In 2012, BAPTA was used by Campo and co-workers for $\mathrm{pH}$ independent caging of $\mathrm{Ca}^{2+}$ as well as its uncaging by photolysis. $^{11}$

For state-of-the-art physiological experiments in living cells and organisms, two-photon (TP) uncaging process using nearinfrared (IR) light is becoming essential. ${ }^{4-9,12-25}$ Alternatively, lanthanide-doped upconversion nanoparticles have also proved to be efficient in recent years. ${ }^{26-32}$ Meanwhile, the threedimensional (3D) resolution achieved using TP excitation is higher than that of one-photon (OP) excitation reactions. Furthermore, the near-IR TP excitation process allows deeper

Received: July 9, 2016

Accepted: July 25, 2016

Published: August 9, 2016 

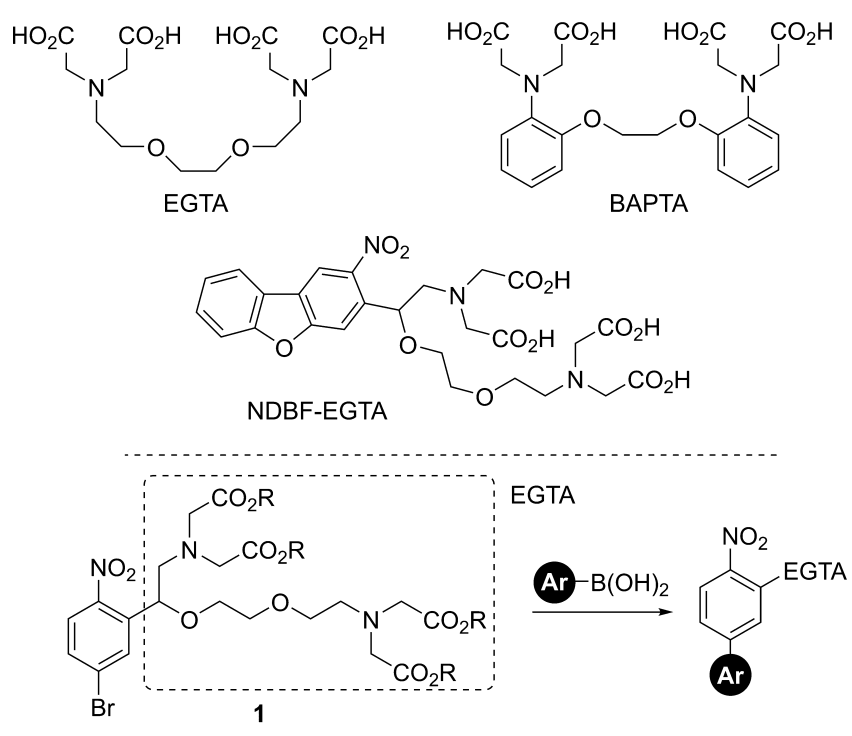

a: $\mathrm{R}=\mathrm{Et} ; \mathbf{b}: \mathrm{R}=\mathrm{CH}_{2} \mathrm{OC}(\mathrm{O}) \mathrm{CH}_{3} ; \mathbf{c}: \mathrm{R}=\mathrm{H}$

Figure 1. Design and synthesis of new TPA chromophores bearing EGTA unit from platform 1a.

penetration of the light beam in living tissue and reduced light scattering. ${ }^{4-9,12-25}$ The optical absorption by endogenous chromophores is also reduced, so less photo-damage to cells is expected. To date, nitrodibenzofuran (NDBF)-substituted EGTA (NDBF-EGTA) ${ }^{5}$ is the only $\mathrm{Ca}^{2+}$ chelator reported to have TP uncaging reactivity when excited at $720 \mathrm{~nm}$ (Figure 1). The TP uncaging cross section $\left(\delta_{\mathrm{u}}\right), \delta_{\mathrm{u}}=\sigma_{2} \times \varphi$, was reported to be $\sim 0.6$ Göppert-Mayer $(\mathrm{GM})^{33}\left(1 \mathrm{GM}=10^{-50} \mathrm{~cm}^{4} \mathrm{~s} /\right.$ photon/molecule). The value of $\sigma_{2}$ is the two-photon absorption (TPA) cross section in GM, and $\varphi$ is the quantum yield of the uncaging reaction. High cross-section GM values in the TP uncaging reaction, for example, $3 \mathrm{GM}^{34}$ have been suggested as a requirement for physiological studies.

In the present study, we report the first and efficient synthesis of 5-bromo-2-nitrobenzyl-substituted EGTA derivative 1a $(\mathrm{R}=\mathrm{Et})$, which is a versatile platform for a new generation of caged calcium compounds (Figure 1). Bromide 1a can be utilized for the synthesis of a wide variety of TPresponsive $\mathrm{Ca}^{2+}$ chelators, using Suzuki-Miyaura coupling reactions. ${ }^{35}$ Thus, the TP absorption maximum and TP reactivity can be tuned by selecting a different aryl group (Ar) in boronic acids $\mathrm{ArB}(\mathrm{OH})_{2}$. Compounds 2 and 3 (Scheme 1 ) were prepared as examples in this study. Efficiencies of TPinduced bond cleavage reactions were found to be as high as $\delta_{\mathrm{u}}$ $=20.7 \mathrm{GM}$ at $740 \mathrm{~nm}$ for $2 \mathrm{a}$ and $\delta_{\mathrm{u}}=7.8 \mathrm{GM}$ at $800 \mathrm{~nm}$ for $3 \mathrm{a}$. The corresponding acetoxymethyl (AM) esters $\mathbf{2 b}$ and $\mathbf{3 b}$ were synthesized and were shown to be effective for in vivo $\mathrm{Ca}^{2+}$ uncaging reaction.

\section{RESULTS AND DISCUSSION}

Synthesis of Compounds 1a, 2, and 3. The synthesis of 1a is summarized in Scheme 1. Commercially available starting material 3-bromo-acetophenone (4) was nitrated ${ }^{36}$ with nitric acid and sulfuric acid to afford nitro-substituted compound $\mathbf{5}$ in $64 \%$ yield. Bromination of 5 with $\mathrm{Br}_{2}$ in the presence of acetic acid in dichloromethane at room temperature (RT) provided the brominated compound in $99 \%$ yield. Without further purification, the keto function of the brominated compound obtained was reduced using sodium borohydride, followed by
Scheme 1. Synthesis of 1a, 2, and $3^{a}$<smiles>CC(C)C(O)c1cc(Br)ccc1[N+](=O)[O-]</smiles><smiles></smiles><smiles>CCOC(=O)CN(CC(=O)OCC)CC(OCCOCCN(CC(=O)OCC)C(=O)OCC)c1cc(Br)ccc1[N+](=O)[O-]</smiles><smiles>[R]OC(=O)CN(CC([R])=O)CC([R])OCCOCC(CN(CC([R])=O)C(=O)[O-])c1cc(Br)ccc1[N+](=O)[O-]</smiles>
b: $\mathrm{R}=\mathrm{CH}_{2} \mathrm{OC}(\mathrm{O}) \mathrm{CH}_{3} ; \mathbf{c}: \mathrm{R}=\mathrm{H}$

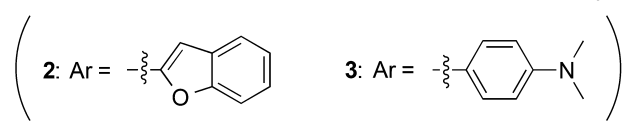

${ }^{a}$ Reagents and conditions: (a) $\mathrm{KNO}_{3}, \mathrm{H}_{2} \mathrm{SO}_{4}, \mathrm{CH}_{2} \mathrm{Cl}_{2}, 0{ }^{\circ} \mathrm{C}-\mathrm{RT}, 4 \mathrm{~h}$, 64\%; (b) $\mathrm{Br}_{2}, \mathrm{AcOH} / \mathrm{CH}_{2} \mathrm{Cl}_{2}, \mathrm{RT}, 55$ h, 99\%; (c) $\mathrm{NaBH}_{4}$, aq $\mathrm{NaOH}$ $(2.5 \mathrm{M})$, 1,4-dioxane/MeOH, $0{ }^{\circ} \mathrm{C}, 1 \mathrm{~h}, 71 \%$; (d) $\mathrm{NaN}_{3}$, DMF, RT$40{ }^{\circ} \mathrm{C}, 4 \mathrm{~h}, 40 \%$; (e) bis(2-bromoethyl) ether, $\mathrm{Cs}_{2} \mathrm{CO}_{3}, \mathrm{ACN}, \mathrm{RT}-50$ ${ }^{\circ} \mathrm{C}, 5 \mathrm{~h}, 53 \%$; (f) $\mathrm{NaN}_{3}$, DMF, RT, 16 h, 80\%; (g) $\mathrm{PPh}_{3}$, RT, $24 \mathrm{~h}$, 80\%; (h) NaI, DIEPA, ethyl bromoacetate, ACN, $0-80{ }^{\circ} \mathrm{C}, 3 \mathrm{~h}, 70 \%$, (i) $\mathrm{ArB}(\mathrm{OH})_{2}, \mathrm{Pd}\left(\mathrm{PPh}_{3}\right)_{4}, \mathrm{~K}_{2} \mathrm{CO}_{3}, \mathrm{THF}, \mathrm{H}_{2} \mathrm{O}, \mathrm{RT}-60^{\circ} \mathrm{C}, 3 \mathrm{~h}, 95 \%$ for $2 \mathrm{a}$ and $90 \%$ for $3 \mathrm{a}$; (j) (I) $\mathrm{KOH}, \mathrm{MeOH}, 0{ }^{\circ} \mathrm{C}-\mathrm{RT}, 16 \mathrm{~h}$; (II) bromomethyl acetate, DIPEA, DMF, $0{ }^{\circ} \mathrm{C}-\mathrm{RT}, 16 \mathrm{~h}, 60 \%$. DIPEA = $\mathrm{N}, \mathrm{N}$-diisopropylethylamine; $\mathrm{THF}=$ tetrahydrofuran; $\mathrm{ACN}=$ acetonitrile.

in situ cyclization under alkaline treatment for $30 \mathrm{~min}$ at $0{ }^{\circ} \mathrm{C}$, giving oxirane 6 in $71 \%$ yield. Epoxide 6 was subsequently treated with sodium azide ${ }^{37}$ in dimethylformamide (DMF) at $40{ }^{\circ} \mathrm{C}$ to afford hydroxyl azide 7 in $40 \%$ yield. This step was the key in our construction of the EGTA unit. The reaction yield was largely dependent on the equivalents of sodium azide and the reaction temperature. After several attempts, 1 equiv $\mathrm{NaN}_{3}$ and $\sim 40{ }^{\circ} \mathrm{C}$ were found to be the best reaction conditions. Hydroxyl azide was alkylated ${ }^{38}$ with bis(2-bromomethyl)ether in the presence of cesium carbonate in DMF at $50{ }^{\circ} \mathrm{C}$ to give compound $\mathbf{8}$ in $53 \%$ yield. The isolated alkylated compound $\mathbf{8}$ was treated with sodium azide at RT to give the diazide ${ }^{39}$ in $80 \%$ yield. The diazide was then converted to diamine 9 in $80 \%$ yield by treatment with $\mathrm{PPh}_{3}$, ${ }^{40}$ followed by hydrolysis. Diamine 9 was alkylated ${ }^{41}$ with ethyl bromoacetate in the presence of sodium iodide in $\mathrm{CH}_{3} \mathrm{CN}$ to give tetraacetic acid derivative $1 \mathrm{a}$ in $70 \%$ yield.

Bromide 1a is a versatile intermediate in Suzuki-Miyaura coupling reactions for producing a new generation of $\mathrm{Ca}^{2+}$ chelators with TPA properties. Numerous TPA chromophores can be prepared from the 1a platform. For example, in this study, bromide 1a was treated with benzofuran-2-boronic acid or 4-(dimethylamino)phenylboronic acid in the presence of $\mathrm{Pd}\left(\mathrm{PPh}_{3}\right)_{4}$ and $\mathrm{K}_{2} \mathrm{CO}_{3}$ to afford EGTA derivatives $2 \mathrm{a}$ or $3 \mathrm{a}$ with benzofuran or biphenyl units as TP chromophores in $95 \%$ and $90 \%$ yield, respectively. Ethyl esters 2a and 3a were hydrolyzed with potassium hydroxide $(\mathrm{KOH})$, followed by esterification with acetoxy methyl (AM) ester to give $\mathbf{2 b}$ and $\mathbf{3 b}$ 

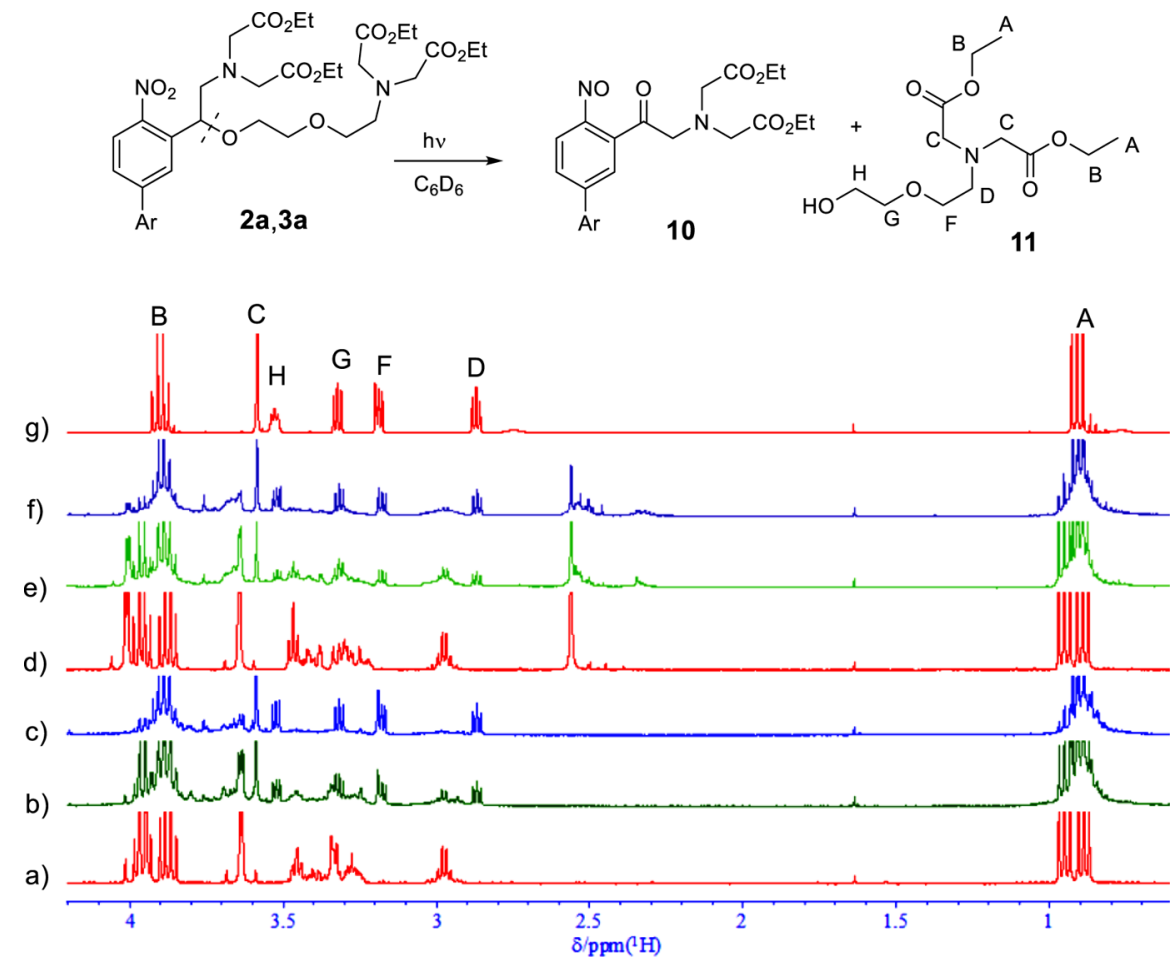

Figure 2. ${ }^{1} \mathrm{H}$ NMR (400 MHz), (a) $\delta 0.5-4.2 \mathrm{ppm}$ of $2 \mathrm{a}$ in $\mathrm{C}_{6} \mathrm{D}_{6}$, (b) after $4 \mathrm{~h}$, and (c) $8 \mathrm{~h}$ irradiation at $360 \mathrm{~nm}$; (d) ${ }^{1} \mathrm{H} \mathrm{NMR}(400 \mathrm{MHz}), \delta 0.5-$ $4.2 \mathrm{ppm}$ of $3 \mathrm{a}$ in $\mathrm{C}_{6} \mathrm{D}_{6}$, (e) after $5 \mathrm{~h}$, and (f) $10 \mathrm{~h}$ irradiation at $400 \mathrm{~nm}$; and $(\mathrm{g}){ }^{1} \mathrm{H}$ NMR $(400 \mathrm{MHz}), \delta 0.5-4.2 \mathrm{ppm}$ of $11 \mathrm{in} \mathrm{C}_{6} \mathrm{D}_{6}$.

(a)

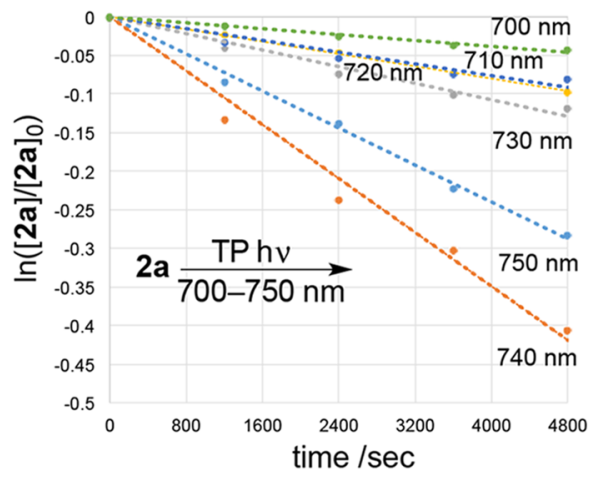

(c)

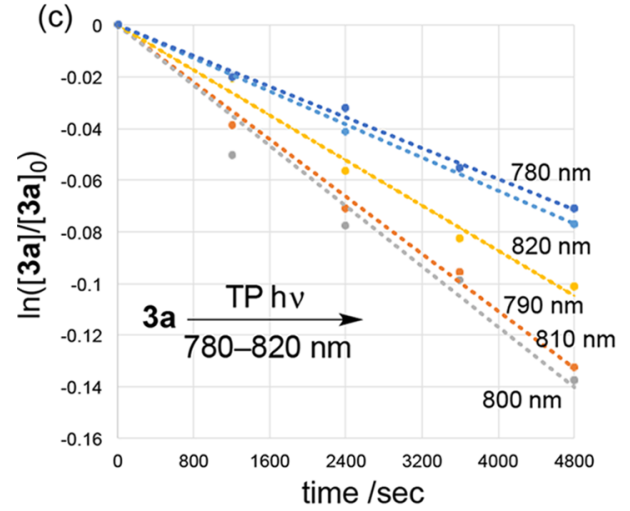

(b)

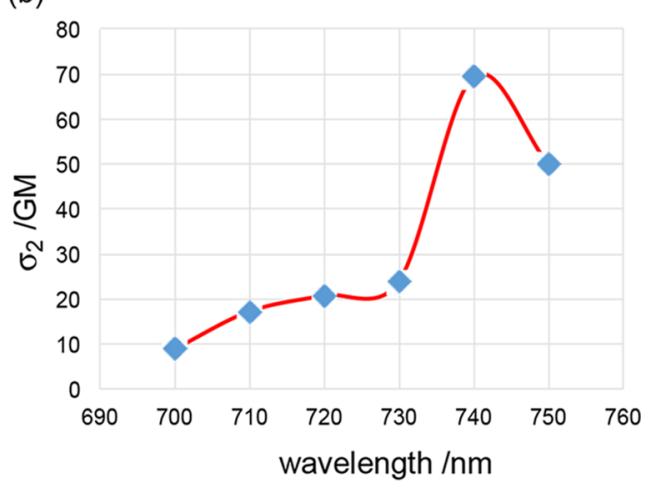

(d)

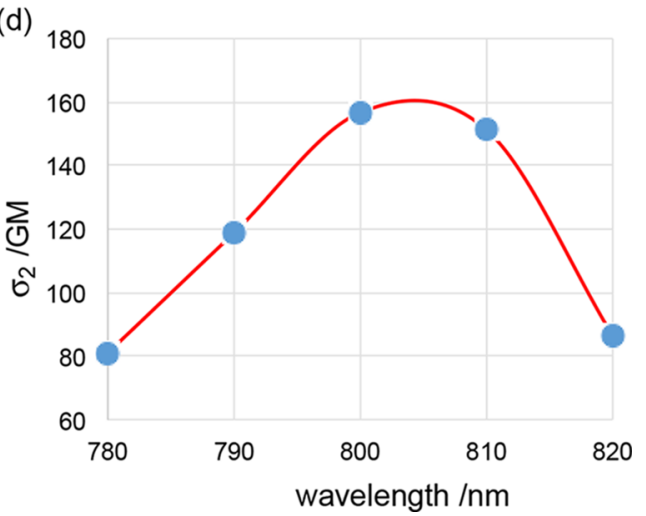

Figure 3. (a) Time profile of TP uncaging of $\mathbf{2 a} \ln \left([\mathbf{2 a}] /[\mathbf{2 a}]_{0}\right)$ vs irradiation time at $700-750 \mathrm{~nm},(\mathrm{~b})$ an action TP absorption spectrum of $\mathbf{2 a},(\mathrm{c})$ time profile of TP uncaging of $3 a \ln \left([3 \mathbf{a}] /[3 \mathbf{a}]_{0}\right)$ vs irradiation time at $780-820 \mathrm{~nm}$, and (d) an action TP absorption spectrum of $3 \mathbf{a}$.

in $60 \%$ yield. AM ester $\mathbf{2 b}$ was loaded into cells to generate intracellular EGTA calcium chelators, vide infra.
OP Photolysis of $2 a$ and $3 a$. The photoreactions of compounds $2 a^{42}$ and $3 a$ were investigated first using an OP excitation process (Figure 2). The OP photochemical reaction 
of $2 \mathrm{a}\left(10 \mathrm{mM}\right.$ in $\mathrm{C}_{6} \mathrm{D}_{6}, \lambda_{\max }=362 \mathrm{~nm}$ with $\varepsilon 18771 \mathrm{M}^{-1}$ $\mathrm{cm}^{-1}$ ) was conducted at $360 \pm 10 \mathrm{~nm}$ using a monochromator with a xenon lamp $(500 \mathrm{~W})$. The photo-induced bond cleavage reaction was monitored using ${ }^{1} \mathrm{H}$ NMR $(400 \mathrm{MHz})$ spectroscopic analysis (Figure 2a-c). As shown in our preliminary results on the photolysis of $2 \mathrm{a},{ }^{42}$ clear decomposition of $2 \mathrm{a}$ was confirmed after irradiation for $8 \mathrm{~h}$. Using ${ }^{1} \mathrm{H}$ NMR analysis, fragmentation product 11 was observed in the photolysate. Compound $\mathbf{1 1}$ was prepared in this study to confirm its formation during the photolysis. The quantum yield $(\varphi)$ of the photochemical decomposition of EGTA ethyl ester 2a was determined to be $0.3 \pm 0.05$ at $360 \mathrm{~nm}$ irradiation using a xenon lamp. Ferric oxalate was used as a chemical actinometer to determine the quantum yield. ${ }^{43}$

The OP bond cleavage reaction of $3 \mathrm{a}\left(10 \mathrm{mM}\right.$ in $\mathrm{C}_{6} \mathrm{D}_{6}, \lambda_{\max }$ $=403 \mathrm{~nm}$ with $\left.\varepsilon 8790 \mathrm{M}^{-1} \mathrm{~cm}^{-1}\right)$ was also conducted at $400 \pm$ $10 \mathrm{~nm}$ using a xenon lamp (Figure $2 \mathrm{~d}-\mathrm{f}$ ). The photo-induced bond cleavage was monitored using ${ }^{1} \mathrm{H}$ NMR (400 $\left.\mathrm{MHz}\right)$ analysis. The complete structural decomposition of compound $3 a$ was observed after irradiation for $10 \mathrm{~h}$. The quantum yield of the decomposition of EGTA ethyl ester 3a was determined to be 0.05 at $400 \mathrm{~nm}$ irradiation.

TP Photolysis of $2 a$ and $3 a$. Photochemical reactions using TP excitation by near-IR light were conducted for $2 a$ and $\mathbf{3 a}$ in dimethyl sulfoxide (DMSO). The TP photolysis of $\mathbf{2 a}$ was performed at $700,710,720,730,740$, and $750 \mathrm{~nm}$ with a Ti:sapphire laser using $\sim 700 \mathrm{~mW}$ at $\sim 25^{\circ} \mathrm{C}$ (Figure 3a,b). The TP photolysis of $3 \mathrm{a}$ was conducted at $780,790,800,810$, and $820 \mathrm{~nm}$ at $\sim 25{ }^{\circ} \mathrm{C}$ (Figure 3c,d). Using high-performance liquid chromatography (HPLC) analysis, TP-induced bond cleavage reactions were monitored by the consumption of $2 \mathbf{a}$ or 3a. Wavelength-dependent changes in the rate constants were determined by the TP decomposition of $\mathbf{2} \mathbf{a}$ or $3 \mathbf{a}$. As reported previously, the absolute value of the TPA cross section for 2-(4nitrophenyl) benzofuran was $18 \mathrm{GM}$ at $720 \mathrm{~nm} .{ }^{42}$ The TP action spectra for $\mathbf{2 a}$ and $3 \mathbf{a}$ were extrapolated in comparison with the standard value. Thus, the TP absorption characters of 2a and 3a were determined to be $\sim 70 \mathrm{GM}$ at $740 \mathrm{~nm}$ and $\sim 160 \mathrm{GM}$ at $800 \mathrm{~nm}$, respectively (Figure 3 ). The TP efficiencies obtained for photochemical decomposition were $20.7 \mathrm{GM}$ at $740 \mathrm{~nm}$ for $2 \mathrm{a}$ and $7.8 \mathrm{GM}$ at $800 \mathrm{~nm}$ for $3 a$.

Measurement of $\mathrm{Ca}^{2+}$ Binding Affinities. The dissociation constants, $K_{d}$, of $\mathrm{Ca}^{2+}$ ions with $2 \mathrm{c}$ and $3 \mathrm{c}(\mathrm{R}=\mathrm{H})$ were determined by a titration method using fluo-3 fluorescent $\mathrm{dye}^{44,45}$ (Figures 5 and 6). Thus, the concentration of free $\mathrm{Ca}^{2+}$ ions, $\left[\mathrm{Ca}^{2+}\right]_{\mathrm{F}}$, after treating $1.0 \mathrm{mM}$ solutions of $2 \mathrm{c}$ and $3 \mathrm{c}$ was determined by fluorescence intensity at $530 \mathrm{~nm}$ from fluo-3 (for a detailed procedure, see Experimental Section). The Scatchard analyses shown in Figures 5 and 6 provided dissociation constants of $K_{\mathrm{d}}=272 \mathrm{nM}$ for $2 \mathrm{c}$ and $K_{\mathrm{d}}=440$ $\mathrm{nM}$ for $3 \mathrm{c}$.

Physiologic Studies of $\mathbf{2 b}$ In Vivo. Because compound 2a had a TP efficiency larger than that of $3 a$, we loaded cultured neurons with $\mathrm{AM}$ ester $2 \mathrm{~b}\left(100 \mu \mathrm{M}, 35^{\circ} \mathrm{C}\right.$ for $\left.40 \mathrm{~min}\right)$ to stimulate presynaptic terminals with TP uncaging. We recorded inhibitory postsynaptic currents (IPSCs) from whole-cellclamped neurons by irradiating with a $720 \mathrm{~nm}$-wavelength femtosecond laser (140 fs, $7.6 \mathrm{~mW}, 1 \mathrm{~ms}$ ) at 100 points, encompassing a small dendritic region (Figure $4 a$ ). The mapping experiments were repeated 81 times in four cells. We recorded IPSCs selectively at dendrite edges, where synapses are most frequently formed. Laser irradiation seldom induced currents over numerous uncaging events on the a)

b)

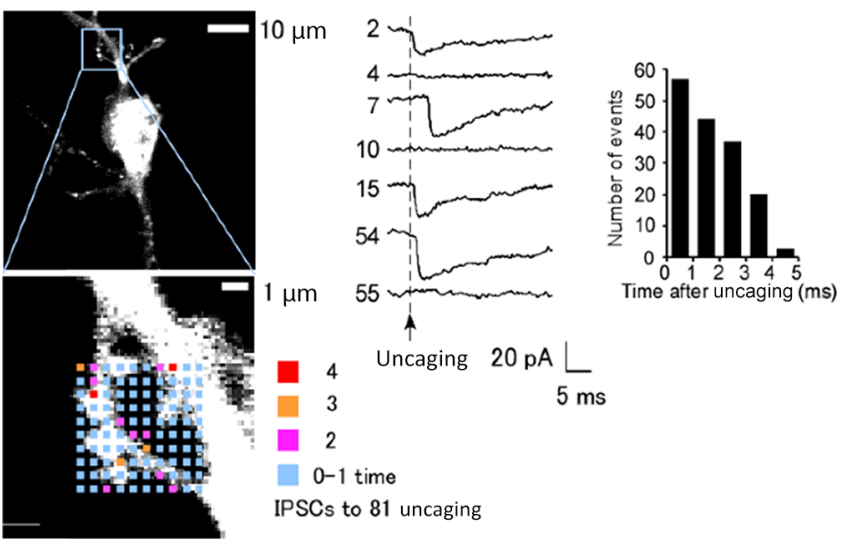

Figure 4. (a) Fluorescence image of a dissociated cultured neuron from cerebral cortices of mice loaded with compound $\mathbf{2 b}$ and a whole cell clamped with Alexa 594 solution. Color squares in the small dendritic region shown in the lower panel indicate the 100 uncaging points separated by $0.55 \mu \mathrm{m}$ for TP uncaging and mapping of the IPSCs. The mapping was repeated 81 times. The IPSCs from each point were recorded $0-4$ times out of 81 sequences, as denoted by color. (b) IPSCs recorded from the single uncaging point of the cell where four IPSCs were recorded. The sequence numbers are shown next to the current traces. (c) Latency histogram for the onset of all uncaging-induced IPSCs recorded from four cells.

dendrites (Figure 4b), supporting that the IPSCs are not caused by damages of the plasma membrane in the presynaptic terminals. The time course and amplitude of the uncaginginduced IPSCs were similar to those of the spontaneous IPSCs, except that they were elicited shortly after uncaging (Figure $4 \mathrm{~b}, \mathrm{c})$. The mean latency of $2.5 \mathrm{~ms}( \pm 0.4 \mathrm{~ms}, n=150)$ was similar to those of IPSCs evoked by electrical stimulation. Uncaging-induced IPSCs were recorded in only up to four out of 81 sequences applied to the dendrite, indicating that the increase in $\left[\mathrm{Ca}^{2+}\right]_{\mathrm{i}}$ was smaller than that induced by action potentials. Thus, we have succeeded in stimulating presynaptic terminals directly by TP uncaging to elicit neurotransmitter release, whereas further improvements to the TP excitation cross section are necessary to make the most of presynaptic terminal stimulation without the action potential.

\section{CONCLUSIONS}

In this study, we designed and synthesized 5-bromo-2nitrobenzyl-substituted EGTA as a platform for a new generation of calcium chelators with TPA properties. The efficient synthesis of this new bromide was accomplished in nine steps from a commercially available starting material. New calcium chelators with TPA properties, that is, TP fragmentation efficiencies of $\delta_{\mathrm{u}}=20.7 \mathrm{GM}$ at $740 \mathrm{~nm}$ for NPBF-EGTA $\left(K_{\mathrm{d}}=272 \mathrm{nM}\right)$ and $\delta_{\mathrm{u}}=7.8 \mathrm{GM}$ at $800 \mathrm{~nm}$ for BP-EGTA $\left(K_{\mathrm{d}}\right.$ $=440 \mathrm{nM})$ derivatives, were synthesized using a SuzukiMiyaura reaction to couple the bromide with benzofuran-2boronic acid and 4-(dimethylamino)phenyl boronic acid, respectively. The corresponding AM esters were synthesized and successfully applied to a $\mathrm{Ca}^{2+}$-uncaging reaction triggered by photolysis in vivo.

\section{EXPERIMENTAL SECTION}

All of the reagents and solvents were reagent grade and used without further purification. Thin-layer chromatography (TLC) 
analysis was performed on silica gel plates and imaged under ultraviolet light. ${ }^{1} \mathrm{H}$ NMR and ${ }^{13} \mathrm{C}$ NMR data were recorded with a $400 \mathrm{MHz} \mathrm{NMR}$ spectrometer. $\mathrm{CD}_{3} \mathrm{OD}$ and $\mathrm{CDCl}_{3}$ [0.03\% trimethylsilane (TMS)] were used as deuterated solvents. Chemical shifts are described in parts per million (ppm) relative to TMS $(\delta=0.00 \mathrm{ppm})$, and the coupling constants $(J)$ are stated in hertz $(\mathrm{Hz})$. High-resolution mass spectroscopy (HRMS) analyses were conducted using an Orbitrap XL instrument in the positive ion mode.

The syntheses of $\mathbf{1 a}, \mathbf{2} \mathbf{a}, \mathbf{3 a}, \mathbf{2} \mathbf{b}$, and $\mathbf{3 b}$ are described below.

1-(5-Bromo-2-nitrophenyl)ethan-1-one (5). A flask was charged with $\mathrm{KNO}_{3}(0.28 \mathrm{~g}, 2.76 \mathrm{mmol})$ and cooled to $0{ }^{\circ} \mathrm{C}$, to which conc. $\mathrm{H}_{2} \mathrm{SO}_{4}(5 \mathrm{~mL})$ was added slowly, and the mixture was stirred for $10 \mathrm{~min}$. 3-Bromoacetophenone (4) (0.5 g, 2.51 $\mathrm{mmol})$ in $\mathrm{CH}_{2} \mathrm{Cl}_{2}(5 \mathrm{~mL})$ was added at $0{ }^{\circ} \mathrm{C}$. The temperature was raised to the RT, and the mixture was stirred for $4 \mathrm{~h}$. Subsequently, the reaction mixture (RM) was poured into crushed ice. An aqueous layer was extracted with $\mathrm{CH}_{2} \mathrm{Cl}_{2}$. The organic layer was washed with brine, dried over $\mathrm{Na}_{2} \mathrm{SO}_{4}$, and purified using silica gel column chromatography to give the required nitro product as a white color solid (400 $\mathrm{mg}, 64 \%$ ). mp 96-98 ${ }^{\circ} \mathrm{C}$. IR $\nu 1710,1558,1521,1345,1308,1241,1087$, 900, 858, 830, 756, $694 \mathrm{~cm}^{-1} ;{ }^{1} \mathrm{H}$ NMR (400 MHz, $\left.\mathrm{CDCl}_{3}\right): \delta$ $8.02(\mathrm{~d}, J=8.7 \mathrm{~Hz}, 1 \mathrm{H}), 7.75(\mathrm{dd}, J=8.7$ and $2.1 \mathrm{~Hz}, 1 \mathrm{H}), 7.56$ $(\mathrm{d}, J=2.1 \mathrm{~Hz}, 1 \mathrm{H}), 2.57(\mathrm{~s}, 3 \mathrm{H}) .{ }^{13} \mathrm{C} \mathrm{NMR}(100 \mathrm{MHz}$, $\left.\mathrm{CDCl}_{3}\right): \delta 198.20,144.31,139.43,133.60,130.34,129.52$, 125.93, 30.21. HRMS-ESI calcd for $\mathrm{C}_{8} \mathrm{H}_{6} \mathrm{BrNO}_{3} \mathrm{Na}[\mathrm{M}+\mathrm{Na}]^{+}$ 265.94233, found 265.94223 .

2-Bromo-1-(5-bromo-2-nitrophenyl)ethan-1-one (S1). To a solution of $5(3.7 \mathrm{~g}, 15.16 \mathrm{mmol})$ in $\mathrm{AcOH}-\mathrm{CH}_{2} \mathrm{Cl}_{2}(1: 2$, $240 \mathrm{~mL})$ was added bromine $(2.42 \mathrm{~g}, 15.2 \mathrm{mmol})$, and the $\mathrm{RM}$ was stirred at RT for $55 \mathrm{~h}$. The solution was evaporated to give S1 (4.89 g, 99\%). mp 100-103 ${ }^{\circ} \mathrm{C}$. IR $\nu$ 1720, 1560, 1540, 1520, 1347, 1185, 861, 831, $701 \mathrm{~cm}^{-1}$; ${ }^{1} \mathrm{H}$ NMR (400 MHz, $\left.\mathrm{CDCl}_{3}\right): \delta 8.12(\mathrm{~d}, J=8.8 \mathrm{~Hz}, 1 \mathrm{H}), 7.81(\mathrm{dd}, J=8.8$ and 2.1 $\mathrm{Hz}, 1 \mathrm{H}), 7.65$ (d, $J=2.1 \mathrm{~Hz}, 1 \mathrm{H}), 4.3(\mathrm{~s}, 2 \mathrm{H}) .{ }^{13} \mathrm{C}$ NMR $(100$ $\left.\mathrm{MHz}, \mathrm{CDCl}_{3}\right): \delta 192.82,144.07,136.36,134.31,132.11$, 130.33, 125.81, 33.46. MS-ESI 321.20.

2-(5-Bromo-2-nitrophenyl) Oxirane (6). To a solution of S1 (1.3 g, $4.02 \mathrm{mmol})$ in dioxane-MeOH (3:1, $40 \mathrm{~mL})$ was added $\mathrm{NaBH}_{4}(156 \mathrm{mg}, 4.02 \mathrm{mmol})$ portionwise at $0{ }^{\circ} \mathrm{C}$, and the $\mathrm{RM}$ was stirred for $30 \mathrm{~min}$ at the same temperature. The mixture was treated with aqueous $\mathrm{NaOH}(25 \mathrm{~mL}, 2.5 \mathrm{~mol} / \mathrm{L})$ and stirred for $30 \mathrm{~min}$ at $0{ }^{\circ} \mathrm{C}$ and then evaporated. The residue was diluted with $\mathrm{CH}_{2} \mathrm{Cl}_{2}(40 \mathrm{~mL})$, washed with water and brine solution, dried over $\mathrm{Na}_{2} \mathrm{SO}_{4}$, and evaporated. Flash column chromatography (hexane/EtOAc $=10: 1$ ) gave a white color solid 6 (710 mg, 71\%). mp $72-75{ }^{\circ} \mathrm{C}$. IR $\nu 1605,1565,1524$, 1514, 1187, 1097, 990, 898, 864, 835, 756, $699 \mathrm{~cm}^{-1}$. ${ }^{1} \mathrm{H}$ NMR $\left(400 \mathrm{MHz}, \mathrm{CDCl}_{3}\right): \delta 8.06(\mathrm{~d}, J=8.7 \mathrm{~Hz}, 1 \mathrm{H}), 7.8(\mathrm{~d}, J=2.2$ $\mathrm{Hz}, 1 \mathrm{H}), 7.63(\mathrm{dd}, J=8.7$ and $2.2 \mathrm{~Hz}, 1 \mathrm{H}), 4.5(\mathrm{dd}, J=4.2$ and $2.5 \mathrm{~Hz}, 1 \mathrm{H}$ ), 3.33 (dd, $J=5.3$ and $4.4 \mathrm{~Hz}, 1 \mathrm{H}), 2.7(\mathrm{dd}, J=5.4$ and $2.5 \mathrm{~Hz}, 1 \mathrm{H}) .{ }^{13} \mathrm{C} \mathrm{NMR}\left(100 \mathrm{MHz}, \mathrm{CDCl}_{3}\right): \delta 146.48$, $136.66,131.83,130.25,129.84,126.27,50.68,50.34$. HRMSAPCI calcd for $\mathrm{C}_{8} \mathrm{H}_{7}{ }^{79} \mathrm{BrNO}_{3} \mathrm{Na}[\mathrm{M}+\mathrm{H}]^{+}$243.96038, found 243.96060 .

2-Azido-1-(5-bromo-2-nitrophenyl)ethan-1-ol (7). To a solution of oxirane $6(400 \mathrm{mg}, 1.63 \mathrm{mmol})$ in freshly distilled dry DMF $(5 \mathrm{~mL})$ was added $\mathrm{NaN}_{3}(106 \mathrm{mg}, 1.63 \mathrm{mmol})$, and the $\mathrm{RM}$ was stirred at $40{ }^{\circ} \mathrm{C}$ for $4 \mathrm{~h}$. The $\mathrm{RM}$ was diluted with EtOAc, washed with water and brine solution, dried over $\mathrm{Na}_{2} \mathrm{SO}_{4}$, and evaporated. Flash column chromatography (hexane $/$ EtOAc $=10: 3)$ gave a yellow color oil $7(120 \mathrm{mg}$,
$40 \%)$. IR $\nu 3500,3100,2946,2870,2130,1604,1570,1533$, 1362, 1321, 1176, 1100, 1061, 907, 848, $758 \mathrm{~cm}^{-1}$; ${ }^{1} \mathrm{H}$ NMR $\left(400 \mathrm{MHz}, \mathrm{CDCl}_{3}\right): \delta 8.11(\mathrm{~d}, J=2.2 \mathrm{~Hz}, 1 \mathrm{H}), 7.94(\mathrm{~d}, J=8.8$ $\mathrm{Hz}, 1 \mathrm{H}), 7.64(\mathrm{dd}, J=8.8$ and $2.2 \mathrm{~Hz}, 1 \mathrm{H}), 5.55(\mathrm{~m}, 1 \mathrm{H}), 3.77$ (dd, $J=12.5$ and $2.8 \mathrm{~Hz}, 1 \mathrm{H}), 3.45(\mathrm{dd}, J=12.5$ and $7.5 \mathrm{~Hz}$, $1 \mathrm{H}), 2.74(\mathrm{~d}, J=3.9 \mathrm{~Hz}, 1 \mathrm{H}) .{ }^{13} \mathrm{C} \mathrm{NMR}\left(100 \mathrm{MHz}, \mathrm{CDCl}_{3}\right): \delta$ 146.02, 138.18, 132.22, 131.97, 129.40, 126.37, 68.80, 57.04. HRMS-ESI calcd for $\mathrm{C}_{8} \mathrm{H}_{7} \mathrm{BrN}_{4} \mathrm{O}_{3} \mathrm{Na}[\mathrm{M}+\mathrm{Na}]^{+} 284.96288$, found 284.96597.

2-(2-Azido-1-(2-(2-bromoethoxy)ethoxy)ethyl)-4bromo-1-nitrobenzene (8). To a stirred suspension of 7 $(600 \mathrm{mg}, 2.09 \mathrm{mmol})$ and cesium carbonate $(3.39 \mathrm{~g}, 10.45$ $\mathrm{mmol})$ in freshly distilled dry acetonitrile $(10 \mathrm{~mL})$ was added bis (2-bromomethyl)ether $(2.42 \mathrm{~g}, 10.45 \mathrm{mmol})$. The mixture was stirred for $5 \mathrm{~h}$ at $50{ }^{\circ} \mathrm{C}$. Then, the $\mathrm{RM}$ was filtered, and the filtrate crude was evaporated using purified flash column chromatography (hexane/EtOAc $=10: 2$ ), which gave a yellow color oil 8 (400 mg, 53\%). IR $\nu$ 2930, 2880, 2114, 1602, 1561, $1530,1465,1362,1303,1120,957,848,757,670 \mathrm{~cm}^{-1} ;{ }^{1} \mathrm{H}$ NMR (400 MHz, $\left.\mathrm{CDCl}_{3}\right): \delta 8.06(\mathrm{~d}, J=2.2 \mathrm{~Hz}, 1 \mathrm{H}), 7.93(\mathrm{~d}, J$ $=8.6 \mathrm{~Hz}, 1 \mathrm{H}), 7.63(\mathrm{dd}, J=8.6$ and $2.2 \mathrm{~Hz}, 1 \mathrm{H}), 5.26(\mathrm{dd}, J=$ 7.2 and $2.8 \mathrm{~Hz}, 1 \mathrm{H}), 3.8-3.4(\mathrm{~m}, 10 \mathrm{H}) .{ }^{13} \mathrm{C} \mathrm{NMR}(100 \mathrm{MHz}$, $\left.\mathrm{CDCl}_{3}\right): \delta 146.90,137.05,132.29,132.19,129.43,126.48$, 77.49, 71.27, 70.47, 69.52, 55.61, 30.20. HRMS-ESI calcd for $\mathrm{C}_{12} \mathrm{H}_{14}{ }^{79} \mathrm{Br}_{2} \mathrm{~N}_{4} \mathrm{O}_{4} \mathrm{Na}[\mathrm{M}+\mathrm{Na}]^{+} 458.92740$, found 458.92767 .

2-(2-Azido-1-(2-(2-azidoethoxy)ethoxy)ethyl)-4bromo-1-nitrobenzene (S2). A solution of 8 (400 mg, 0.91 mmol) and sodium azide $(118 \mathrm{mg}, 1.82 \mathrm{mmol})$ in dry DMF (4 $\mathrm{mL}$ ) was stirred at RT for $16 \mathrm{~h}$. Then the RM was diluted with EtOAc, washed with water and brine solution, dried over $\mathrm{Na}_{2} \mathrm{SO}_{4}$, and evaporated. Flash column chromatography (hexane/EtOAc $=10: 3)$ gave a yellow color oil S2 $(295 \mathrm{mg}$, $80 \%)$. IR $\nu 2937,2882,2127,1597,1560,1538,1449,1370$, 1320, 1170, 848, $755 \mathrm{~cm}^{-1}$. ${ }^{1} \mathrm{H}$ NMR (400 MHz, $\left.\mathrm{CDCl}_{3}\right): \delta$ $8.08(\mathrm{~d}, J=2.2 \mathrm{~Hz}, 1 \mathrm{H}), 7.95(\mathrm{~d}, J=8.7 \mathrm{~Hz}, 1 \mathrm{H}), 7.65$ (dd, $J=$ 8.7 and $2.2 \mathrm{~Hz}, 1 \mathrm{H}), 5.28(\mathrm{dd}, J=7.2$ and $2.9 \mathrm{~Hz}, 1 \mathrm{H}), 3.76-$ $3.58(\mathrm{~m}, 6 \mathrm{H}), 3.56-3.39(\mathrm{~m}, 4 \mathrm{H}) .{ }^{13} \mathrm{C}$ NMR $(100 \mathrm{MHz}$, $\left.\mathrm{CDCl}_{3}\right): \delta 146.90,137.04,132.28,132.17,129.41,126.48$, $77.49,70.58,70.17,69.55,55.59,50.68 \mathrm{~cm}^{-1}$. HRMS-ESI calcd for $\mathrm{C}_{12} \mathrm{H}_{14}{ }^{79} \mathrm{BrN}_{7} \mathrm{O}_{4} \mathrm{Na}[\mathrm{M}+\mathrm{Na}]^{+} 422.01829$, found 422.01773 .

2-(2-(2-Aminoethoxy)ethoxy)-2-(5-bromo-2nitrophenyl)ethan-1-amine (9). To a solution of compound S2 $(520 \mathrm{mg}, 1.3 \mathrm{mmol})$ in THF $(5 \mathrm{~mL})$ was added $\mathrm{PPh}_{3}(1.02$ $\mathrm{g}, 3.9 \mathrm{mmol}$ ), and the RM was stirred for $12 \mathrm{~h}$ at RT. Then $\mathrm{H}_{2} \mathrm{O}(0.5 \mathrm{~mL})$ was added, and the resulting solution was stirred for $12 \mathrm{~h}$. The solvent was evaporated, and the reaction products were purified using flash column chromatography $\left(\mathrm{CH}_{2} \mathrm{Cl}_{2} /\right.$ $\left.\mathrm{MeOH} / \mathrm{Et}_{3} \mathrm{~N}=7: 2: 1\right)$, which gave a yellow color liquid 9 (360 $\mathrm{mg}, 80 \%)$. IR $\nu 3442,2933,1531,1359,1129,845,658 \mathrm{~cm}^{-1}$; ${ }^{1} \mathrm{H}$ NMR (400 MHz, $\mathrm{CDCl}_{3}$ ): $\delta 7.99(\mathrm{~d}, J=2.1 \mathrm{~Hz}, 1 \mathrm{H}), 7.92$ $(\mathrm{d}, J=8.7 \mathrm{~Hz}, 1 \mathrm{H}), 7.61(\mathrm{dd}, J=8.7$ and $2.1 \mathrm{~Hz}, 1 \mathrm{H}), 5.1(\mathrm{dd}, J$ $=8.1$ and $2.6 \mathrm{~Hz}, 1 \mathrm{H}), 3.72-3.51(\mathrm{~m}, 6 \mathrm{H}), 3.33-2.82(\mathrm{~m}, 4 \mathrm{H})$, 2.03 (bs, $2 \mathrm{H}), 1.41(\mathrm{t}, J=7.5 \mathrm{~Hz}, 2 \mathrm{H}) .{ }^{13} \mathrm{C} \mathrm{NMR}(100 \mathrm{MHz}$, $\left.\mathrm{CDCl}_{3}\right): \delta 147.22,138.14,131.95,131.68,129.20,126.45$, 77.23, 71.1, 70.12, 69.13, 47.33, 40.88. HRMS-ESI calcd for $\mathrm{C}_{12} \mathrm{H}_{18}{ }^{79} \mathrm{BrN}_{3} \mathrm{O}_{4} \mathrm{Na}[\mathrm{M}+\mathrm{Na}]^{+}$370.03729, found 370.03726 .

Diethyl-5-(5-bromo-2-nitrophenyl)-3,12-bis(2-ethoxy2-oxoethyl)-6,9-dioxa-3,12-diazatetradecanedioate (1a). To a solution of 9 ( $800 \mathrm{mg}, 2.3 \mathrm{mmol})$, sodium iodide $(3.45 \mathrm{~g}$, $23.05 \mathrm{mmol})$, and diisopropyl ethylamine $(1.48 \mathrm{~g}, 11.52 \mathrm{mmol})$ in dry $\mathrm{CH}_{3} \mathrm{CN}(30 \mathrm{~mL})$, ethyl bromoacteate (3.85 g, 23.05 $\mathrm{mmol}$ ) was added dropwise at $0{ }^{\circ} \mathrm{C}$, and the $\mathrm{RM}$ was stirred for 
$3 \mathrm{~h}$ at $80{ }^{\circ} \mathrm{C}$. The $\mathrm{RM}$ was filtered, and the filtrate was evaporated. Flash column chromatography (hexane $/$ EtOAc $=$ 2:1) gave a pale yellow color oil 1a (1.1 g, 70\%). IR $\nu 2985$, 1752, 1600, 1530, 1211, 1045, 759, $602 \mathrm{~cm}^{-1}$; ${ }^{1} \mathrm{H}$ NMR (400 $\left.\mathrm{MHz}, \mathrm{CDCl}_{3}\right): \delta 7.98(\mathrm{~d}, J=2.1 \mathrm{~Hz}, 1 \mathrm{H}), 7.86(\mathrm{~d}, J=8.7 \mathrm{~Hz}$, $1 \mathrm{H}), 7.54(\mathrm{dd}, J=8.7$ and $2.1 \mathrm{~Hz}, 1 \mathrm{H}), 5.2(\mathrm{dd}, J=7.2$ and 3.3 $\mathrm{Hz}, 1 \mathrm{H}), 4.19-4.11(\mathrm{~m}, 8 \mathrm{H}), 3.78-3.67(\mathrm{~m}, 4 \mathrm{H}), 3.62-3.38$ (m, 10H), 3.09-2.91 (m, 4H) $1.29-1.22(\mathrm{~m}, 12 \mathrm{H}) .{ }^{13} \mathrm{C}$ NMR $\left(100 \mathrm{MHz}, \mathrm{CDCl}_{3}\right): \delta 171.70,171.41,146.97,139.13,132.10$, $131.43,128.98,126.16,77.80,70.32,70.18,69.14,61.17,60.45$, $55.98,55.73,53.84$, 14.27. HRMS-ESI calcd for $\mathrm{C}_{28} \mathrm{H}_{42} \mathrm{BrN}_{3} \mathrm{O}_{12} \mathrm{Na}[\mathrm{M}+\mathrm{Na}]^{+} 714.18441$, found 714.18518.

Diethyl-5-(5-benzofuran-2-yl)-2-nitrophenyl)-3,12bis(2-ethoxy-2-oxoethyl)-6,9-dioxa-3,12-diazatetradecanedioate (2a). A solution of $1 \mathrm{a}(200 \mathrm{mg}, 0.28 \mathrm{mmol})$, benzofuran-2-boronic acid (52.4 mg, $0.31 \mathrm{mmol}), \mathrm{Pd}\left(\mathrm{PPh}_{3}\right)_{4}$ $(16.7 \mathrm{mg}, 0.14 \mathrm{mmol})$, and potassium carbonate $(52 \mathrm{mg}, 0.31$ mmol) was taken in $10 \mathrm{~mL} \mathrm{THF} / \mathrm{H}_{2} \mathrm{O}(9: 1)$ in a round-bottom flask and was stirred for $3 \mathrm{~h}$ at $60{ }^{\circ} \mathrm{C}$. Then, the reaction mixture was filtered. The filtrate was washed with water, extracted with EtOAc organic layer, dried over $\mathrm{Na}_{2} \mathrm{SO}_{4}$, evaporated under reduced pressure, and purified using column chromatography to afford the desire compound as a yellow oil 2a (95\%). IR $\nu 2974,2903,2859,1730,1610,1515,1445$, 1346, 1255, 1178, 1024, 746. ${ }^{1} \mathrm{H}$ NMR (400 MHz, $\left.\mathrm{CDCl}_{3}\right): \delta$ $8.29(\mathrm{~s}, 1 \mathrm{H}), 8.1(\mathrm{~d}, J=8.6 \mathrm{~Hz}, 1 \mathrm{H}), 7.9(\mathrm{dd}, J=2.0$ and 8.6 $\mathrm{Hz}, 1 \mathrm{H}), 7.68(\mathrm{~d}, J=7.7 \mathrm{~Hz}, 1 \mathrm{H}), 7.6(\mathrm{~d}, J=8.1 \mathrm{~Hz}, 1 \mathrm{H}), 7.4-$ $7.29(\mathrm{~m}, 3 \mathrm{H}), 5.34-5.3(\mathrm{~m}, 1 \mathrm{H}), 4.22-4.07(\mathrm{~m}, 8 \mathrm{H}), 3.8(\mathrm{~s}$, $4 \mathrm{H}), 3.65-3.5(\mathrm{~m}, 10 \mathrm{H}), 3.17-2.9(\mathrm{~m}, 4 \mathrm{H}), 1.31-1.3(\mathrm{~m}$, $12 \mathrm{H}) .{ }^{13} \mathrm{C}$ NMR $\left(100 \mathrm{MHz}, \mathrm{CDCl}_{3}\right): \delta 171.82,171.34,170.19$, 155.42 , 147.24, 128.74, 125.68, 124.77, 124.04, 123.45, 121.65, 111.53, 105.18, 78.16, 77.35, 77.24, 77.03, 76.72, 70.29, 69.06, 61.30, 60.42, 55.87, 55.75, 53.71, 21.08, 14.28, 14.22. HRMSESI calcd for $\mathrm{C}_{36} \mathrm{H}_{47} \mathrm{~N}_{3} \mathrm{O}_{13} \mathrm{Na}[\mathrm{M}+\mathrm{Na}]^{+} 752.30011$, found 752.30011 .

Diethyl-5-(4'-(dimethylamino)-4-nitro-[1,1'-biphenyl]3-yl)-3,12-bis(2-ethoxy-2-oxoethyl)-6,9-dioxa-3,12-diazatetradecanedioate (3a). A solution of 1 a $(200 \mathrm{mg}, 0.28$ $\mathrm{mmol}), 4-(\mathrm{N}, \mathrm{N}$-dimethyl amino)phenylboronic acid $(52.4 \mathrm{mg}$, $0.31 \mathrm{mmol}), \mathrm{Pd}\left(\mathrm{PPh}_{3}\right)_{4}(16.7 \mathrm{mg}, 0.14 \mathrm{mmol})$, and potassium carbonate $(60 \mathrm{mg}, 0.43 \mathrm{mmol})$ was taken in $10 \mathrm{~mL} \mathrm{THF} / \mathrm{H}_{2} \mathrm{O}$ (9:1) in a round-bottom flask and was stirred for $3 \mathrm{~h}$ at $60^{\circ} \mathrm{C}$. Then, the reaction mixture was filtered. The filtrate was washed with water, extracted with EtOAc organic layer, dried over $\mathrm{Na}_{2} \mathrm{SO}_{4}$, evaporated under reduced pressure, and purified using column chromatography to afford the desire compound as a yellow oil 3a (90\%): ${ }^{1} \mathrm{H}$ NMR $\left(400 \mathrm{MHz}, \mathrm{CDCl}_{3}\right): \delta 8.27(\mathrm{~d}, J$ $=2.1 \mathrm{~Hz}, 1 \mathrm{H}), 7.84(\mathrm{~d}, J=8.6 \mathrm{~Hz}, 1 \mathrm{H}), 7.64-7.6(\mathrm{~m}, 2 \mathrm{H})$, $7.19(\mathrm{dd}, J=2.2$ and $2.1 \mathrm{~Hz}, 1 \mathrm{H}), 6.71-6.67(\mathrm{~m}, 2 \mathrm{H}), 5.32$ (dd, $J=8.3$ and $2.3 \mathrm{~Hz}, 1 \mathrm{H}), 4.03-3.84(\mathrm{~m}, 12 \mathrm{H}), 3.65-3.62$ (m, $4 \mathrm{H}), 3.48-3.2(\mathrm{~m}, 8 \mathrm{H}), 3.16-2.85(\mathrm{~m}, 8 \mathrm{H}), 0.95(\mathrm{t}, J=$ $7.2 \mathrm{~Hz}, 6 \mathrm{H}), 0.89(\mathrm{t}, J=7.2 \mathrm{~Hz}, 6 \mathrm{H}) .{ }^{13} \mathrm{C} \mathrm{NMR}(100 \mathrm{MHz}$, $\left.\mathrm{CDCl}_{3}\right): \delta 171.80,171.31,150.95,146.67,145.60,137.69$, $128.11,125.83,125.68,125.25,124.89,112.49,78.28,77.22$, 70.33, 70.24, 68.83, 61.46, 60.39, 60.37, 55.88, 55.68, 53.73, $40.31,14.28,14.22$. HRMS-ESI calcd for $\mathrm{C}_{36} \mathrm{H}_{52} \mathrm{~N}_{4} \mathrm{O}_{12} \mathrm{Na}[\mathrm{M}+$ $\mathrm{Na}]^{+}$755.34739, found 755.34631 .

Bis(acetoxymethyl) 3,12-Bis(2-(acetoxymethoxy)-2oxoethyl)-5-(5-(benzofuran-2-yl)-2-nitrophenyl)-6,9dioxa-3,12-diazatetradecanedioate (2b). To a compound 2a (50 mg, $0.068 \mathrm{mmol}$ ) in $3 \mathrm{~mL}$ of $\mathrm{MeOH}$ was added potassium hydroxide $(\mathrm{KOH})(19.2 \mathrm{mg}, 0.34 \mathrm{mmol})$ at $0{ }^{\circ} \mathrm{C}$. The $\mathrm{RM}$ was stirred for $2 \mathrm{~h}$ at $60^{\circ} \mathrm{C}$, evaporated under reduced pressure, and dried over. The yellow color solid obtained was dissolved in freshly distilled dry DMF (3 mL). Diisopropylethyl amine (52 mg, $0.4 \mathrm{mmol}$ ) and bromomethylacetate (166 mg, $1.08 \mathrm{mmol}$ ) were added at $0{ }^{\circ} \mathrm{C}$. After $16 \mathrm{~h}$ of stirring at RT, the RM was diluted with water and extracted with ethyl acetate. The organic layer was washed with water and brine solution, dried over $\mathrm{Na}_{2} \mathrm{SO}_{4}$, and evaporated under reduced pressure. The reaction products were purified using silica gel column chromatography and further purified by recycling HPLC with gel permeation chromatography (GPC) column to give pure AM ester as a yellow color oil $\mathbf{2 b}(60 \%) .{ }^{1} \mathrm{H}$ NMR (400 MHz, $\left.\mathrm{CDCl}_{3}\right): \delta 8.27(\mathrm{~d}, J=2.0 \mathrm{~Hz}, 1 \mathrm{H}), 8.16(\mathrm{~d}, J=8.7 \mathrm{~Hz}, 1 \mathrm{H})$, $7.93(\mathrm{dd}, J=8.6$ and $2.0 \mathrm{~Hz}, 1 \mathrm{H}), 7.68(\mathrm{~d}, J=8.6 \mathrm{~Hz}, 1 \mathrm{H}), 7.61$ $(\mathrm{d}, J=8.2 \mathrm{~Hz}, 1 \mathrm{H}), 7.4-7.37(\mathrm{~m}, 1 \mathrm{H}), 7.31-7.24(\mathrm{~m}, 2 \mathrm{H})$, $5.79(\mathrm{~s}, 4 \mathrm{H}), 5.9(\mathrm{~s}, 4 \mathrm{H}), 5.31(\mathrm{dd}, J=7.9$ and $2.45 \mathrm{~Hz}, 1 \mathrm{H})$, 3.94-3.84 (m, 4H), 3.67-3.47 (m, 10H), 3.23-3.09 (m, 2H), $2.99-2.86(\mathrm{~m}, 2 \mathrm{H}), 2.13(\mathrm{~s}, 6 \mathrm{H}), 2.08(\mathrm{~s}, 6 \mathrm{H}) .{ }^{13} \mathrm{C}$ NMR $(100$ $\left.\mathrm{MHz}, \mathrm{CDCl}_{3}\right): \delta 170.51,170.01,169.73,169.51,155.45$, $153.30,147.12$, 137.80, 135.66, 132.12, 132.10, 128.61, 128.58, $125.74,124.52,124.11,123.53,121.60,111.57,105.30,79.14$, 78.17, 77.25, 70.34, 70.29, 69.05, 61.10, 55.43, 55.36, 53.53, 20.77, 20.71. HRMS-ESI calcd for $\mathrm{C}_{40} \mathrm{H}_{47} \mathrm{~N}_{3} \mathrm{O}_{21} \mathrm{Na}[\mathrm{M}+\mathrm{Na}]^{+}$ 928.25943, found 928.25897 .

Bis(acetoxymethyl) 3,12-Bis(2-(acetoxymethoxy)-2oxoethyl)-5-(4' -(dimethylamino)-4-nitro-[1,1'-biphenyl]3-yl)-6,9-dioxa-3,12-diazatetradecanedioate (3b). To the compound 3a (50 mg, $0.068 \mathrm{mmol})$ in $3 \mathrm{~mL}$ of $\mathrm{MeOH}$ was added $\mathrm{KOH}(19.1 \mathrm{mg}, 0.34 \mathrm{mmol})$ at $0{ }^{\circ} \mathrm{C}$. The $\mathrm{RM}$ was stirred for $2 \mathrm{~h}$ at $60{ }^{\circ} \mathrm{C}$, evaporated under reduced pressure, and dried over. The yellow color solid obtained was dissolved in freshly distilled dry DMF $(3 \mathrm{~mL})$. Diisopropylethyl amine and bromomethylacetate were added at $0{ }^{\circ} \mathrm{C}$. After $16 \mathrm{~h}$ of stirring at RT, the RM was diluted with water and extracted with ethyl acetate. The organic layer was washed with water and brine solution, dried over $\mathrm{Na}_{2} \mathrm{SO}_{4}$, and evaporated under reduced pressure. The reaction products were purified using silica gel column chromatography and further purified by recycling HPLC with GPC column to give pure AM ester as a yellow color oil 3b (60\%). ${ }^{1} \mathrm{H}$ NMR (400 MHz, $\left.\mathrm{CDCl}_{3}\right): \delta 8.09$ (d, $J=$ $8.7 \mathrm{~Hz}, 1 \mathrm{H}), 7.96(\mathrm{~d}, J=2.1 \mathrm{~Hz}, 1 \mathrm{H}), 7.63-7.57(\mathrm{~m}, 3 \mathrm{H})$, 6.84-6.8 (m, $J=8.9,2 \mathrm{H}), 5.79(\mathrm{~s}, 4 \mathrm{H}), 5.72(\mathrm{~s}, 4 \mathrm{H}), 5.32(\mathrm{dd}$, $J=8.3$ and $1.8 \mathrm{~Hz}, 1 \mathrm{H}), 3.91(\mathrm{~s}, 4 \mathrm{H}), 3.65-3.44(\mathrm{~m}, 10 \mathrm{H})$, 3.23-3.02 (m, 8H), 2.97-2.84 (m, 2H), $2.14(\mathrm{~s}, 6 \mathrm{H}), 2.1(\mathrm{~s}$, $6 \mathrm{H}) .{ }^{13} \mathrm{C} \mathrm{NMR}\left(100 \mathrm{MHz}, \mathrm{CDCl}_{3}\right): \delta 170.63,170.10,169.71$, $169.58,150.97,146.71,145.45,137.41,128.19,125.84,125.63$, $125.03,112.46,79.12,78.25,77.23,70.31,68.74,61.19,55.41$, $55.20,53.63,40.31,20.79$, 20.72. HRMS-ESI calcd for $\mathrm{C}_{40} \mathrm{H}_{52} \mathrm{~N}_{4} \mathrm{O}_{20} \mathrm{Na}[\mathrm{M}+\mathrm{Na}]^{+}$931.30671, found 931.30420.

5-(5-(Benzofuran-2-yl)-2-nitrophenyl)-3,12-bis(carboxymethyl)-6,9-dioxa-3,12-diazatetradecanedioic acid (2c). Tetraethyl ester 2a (100 mg, $0.13 \mathrm{mmol}$ ) was dissolved in methanol $(4 \mathrm{~mL})$ and then saponified by the addition of $\mathrm{KOH}(38.4 \mathrm{mg}, 0.68 \mathrm{mmol})$ and stirring for $2 \mathrm{~h}$ at $60{ }^{\circ} \mathrm{C}$. After evaporation of methanol and acidification with $2 \mathrm{~N}$ aqueous $\mathrm{HCl}$ to $\mathrm{pH} 2$, the yellow solid obtained was collected and dried to afford $2 \mathrm{c}(92 \%) .{ }^{1} \mathrm{H}$ NMR (400 MHz, $\left.\mathrm{CD}_{3} \mathrm{OD}\right): \delta$ $8.32-8.30$ (bs, $1 \mathrm{H}), 8.24(\mathrm{~d}, J=8.6 \mathrm{~Hz}, 1 \mathrm{H}), 8.13$ (dd, $J=1.8$ and $8.6 \mathrm{~Hz}, 1 \mathrm{H}), 7.71(\mathrm{~d}, J=7.5 \mathrm{~Hz}, 1 \mathrm{H}), 7.62-7.56(\mathrm{~m}, 2 \mathrm{H})$, 7.4-7.28 (m, 2H), $5.65(\mathrm{~m}, 1 \mathrm{H}), 4.5$ (bs, 4H), 4.15 (bs, 4H), 4.0-3.5 (m, 10H). ${ }^{13} \mathrm{C}$ NMR (100 MHz, $\left.\mathrm{CD}_{3} \mathrm{OD}\right): 168.86$, $168.47,157.06,154.37,148.86,137.65$, 135.27, 130.31, 127.77, $127.47,127.27,125.71,125.05,123.30,112.58,107.5,74.69$, 71.48, 69.75, 66.85, 66.81, 60.87, 57.43, 57.38, 56.66, 54.02. 

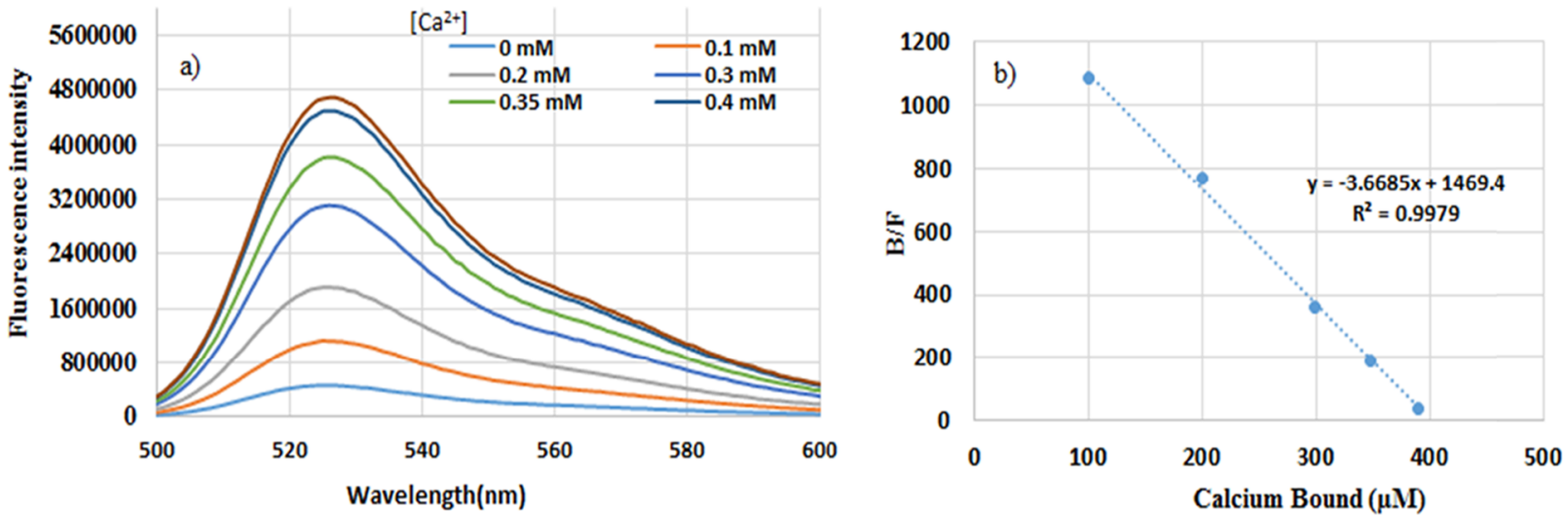

Figure 5. (a) Emission spectra of fluo-3 $(10 \mu \mathrm{M}$, excitation at $490 \mathrm{~nm})$ resulting from the titration of $2 \mathrm{c}(1.0 \mathrm{mM}$ in $\mathrm{Hepes} / 100 \mathrm{mM} \mathrm{KCl}$, pH 7.4 at $298 \mathrm{~K}$ ) with incremental addition of $\mathrm{Ca}^{2+}$. (b) Scatchard analysis (using $K_{\mathrm{d}}$ value of $500 \mathrm{nM}$ for fluo-3) of these data.
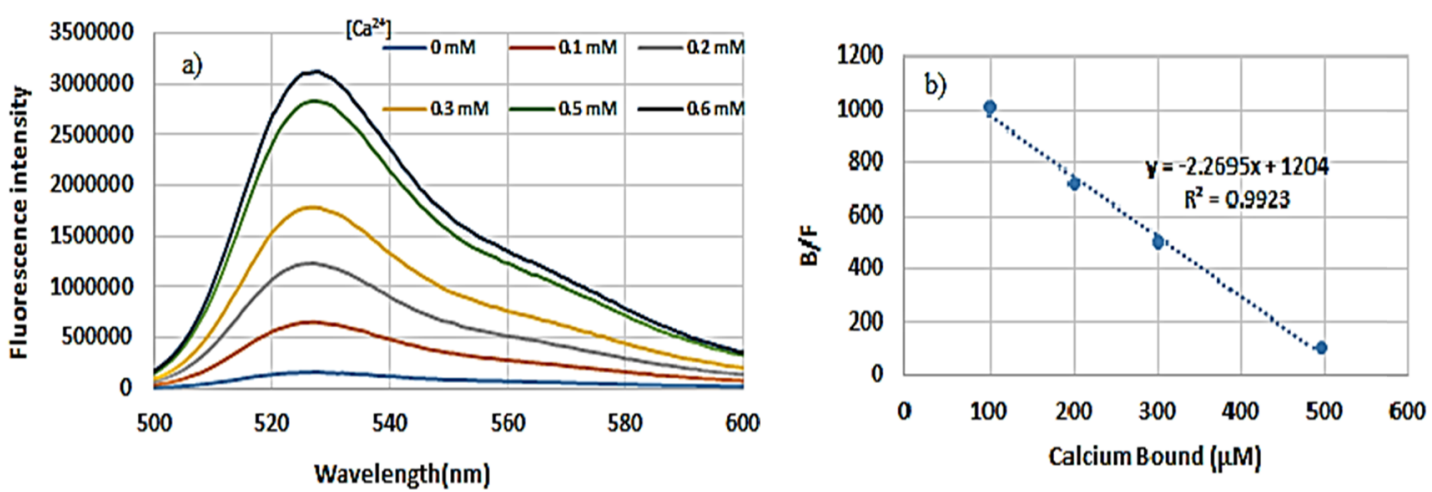

Figure 6. (a) Emission spectra of fluo-3 $(10 \mu \mathrm{M}$, excitation at $490 \mathrm{~nm})$ resulting from the titration of $3 \mathrm{c}(1.0 \mathrm{mM}$ in $\mathrm{Hepes} / 100 \mathrm{mM} \mathrm{KCl}, \mathrm{pH} 7.4$ at $298 \mathrm{~K}$ ) with incremental addition of $\mathrm{Ca}^{2+}$. (b) Scatchard analysis (using $K_{\mathrm{d}}$ value of $500 \mathrm{nM}$ for fluo-3) of these data.

HRMS-ESI calcd for $\mathrm{C}_{28} \mathrm{H}_{31} \mathrm{~N}_{3} \mathrm{O}_{13}[\mathrm{M}-\mathrm{H}]^{+}$616.17841, found 616.17767.

3,12-Bis(carboxymethyl)-5-(4'-(dimethylamino)-4nitro-[1,1' -biphenyl]-3-yl)-6,9-dioxa-3,12-diazatetradecanedioic acid (3c). Tetraethyl ester $3 \mathrm{a}(100 \mathrm{mg}, 0.13 \mathrm{mmol})$ was dissolved in methanol $(4 \mathrm{~mL})$ and then saponified by the addition of $\mathrm{KOH}(38.3 \mathrm{mg}, 0.68 \mathrm{mmol})$ and stirring for $2 \mathrm{~h}$ at $60{ }^{\circ} \mathrm{C}$. After evaporation of methanol and acidification with $2 \mathrm{~N}$ aqueous $\mathrm{HCl}$ to $\mathrm{pH} 2$, the yellow solid obtained was collected and dried to afford $3 \mathrm{c}(90 \%) .{ }^{1} \mathrm{H} \mathrm{NMR}\left(400 \mathrm{MHz}, \mathrm{CD}_{3} \mathrm{OD}\right): \delta$ $8.15(\mathrm{~d}, J=8.4 \mathrm{~Hz}, 1 \mathrm{H}), 8.05(\mathrm{~s}, 1 \mathrm{H}), 7.95-7.85(\mathrm{~m}, 3 \mathrm{H})$, $7.81-7.65(\mathrm{~m}, 2 \mathrm{H}), 5.62-5.58(\mathrm{~m}, 1 \mathrm{H}), 4.46(\mathrm{~s}, 2 \mathrm{H}), 4.45(\mathrm{~s}$, $2 \mathrm{H}), 4.17$ (s, 2H), $4.16(\mathrm{~s}, 2 \mathrm{H}), 3.94-3.73(\mathrm{~m}, 4 \mathrm{H}), 3.66-3.45$ (m, 6H), $3.27(\mathrm{~s}, 6 \mathrm{H}) .{ }^{13} \mathrm{C} \mathrm{NMR}\left(100 \mathrm{MHz}, \mathrm{CD}_{3} \mathrm{OD}\right): 168.72$, 168.42 , 149.21, 146.64, 145.04, 141.1, 134.77, 130.94, 130.05, 128.67, 127.68, 112.80, 74.67, 71.44, 69.73, 66.91, 60.91, 57.34, 56.67, 47.27. HRMS-ESI calcd for $\mathrm{C}_{28} \mathrm{H}_{36} \mathrm{~N}_{4} \mathrm{O}_{12}[\mathrm{M}+\mathrm{H}]^{+}$ 621.24025, found 621.24084.

Calcium Binding Affinities. The association constant for the two chelators $2 \mathrm{c}$ and $3 \mathrm{c}$ was calculated using the method of Ellis-Davies et al. by the equation

$$
\left[\mathrm{Ca}^{2+}\right]_{\mathrm{B}} /\left[\mathrm{Ca}^{2+}\right]_{\mathrm{F}}=K_{\mathrm{a}}\left([\text { chelator }]_{\mathrm{T}}-\left[\mathrm{Ca}^{2+}\right]_{\mathrm{B}}\right)
$$

Here $\left[\mathrm{Ca}^{2+}\right]_{\mathrm{B}}$ is the concentration of $\mathrm{Ca}^{2+}$ bound to the chelator, $\left[\mathrm{Ca}^{2+}\right]_{\mathrm{F}}$ is the concentration of the free $\mathrm{Ca}^{2+}$, and $[\text { chelator }]_{\mathrm{T}}$ is the total concentration of the chelator (NPBFEGTA acid or BP-EGTA acid) in the solution. The free and bound calcium concentrations were obtained from the emission spectra of a calcium-sensitive dye (fluo-3, $K_{\mathrm{d}}=500 \mathrm{~nm}$ ) through titration with calcium chloride solution.

In this measurement, chelators $(1.0 \mathrm{mM})$, fluo-3 $(0.01 \mathrm{mM})$, Hepes $(10 \mathrm{mM}) \mathrm{pH} 7.4$, and $100 \mathrm{mM} \mathrm{KCl}$ solutions were used. A $3.0 \mathrm{~mL}$ solution of $1.0 \mathrm{mM}$ chelator was used. The solution was buffered to $\mathrm{pH} 7.4$ with Hepes, and the ionic strength was set with $100 \mathrm{mM} \mathrm{KCl}$. Data from the titration with incremental addition of $\mathrm{Ca}^{2+}$ are shown in Figures 5 and 6.

$\left[\mathrm{Ca}^{2+}\right]_{\mathrm{B}} /\left[\mathrm{Ca}^{2+}\right]_{\mathrm{F}}$ were obtained from the absorption curves shown in Figures 5 and 6 . The concentration of chelators was $1.0 \mathrm{mM}$, and the $\mathrm{CaCl}_{2}$ concentrations were $0.1,0.2,0.3,0.35$, 0.4 , and $0.5 \mathrm{mM}$ for NPBF-EGTA acid and 0.1, 0.2, 0.3, 0.5, and $0.6 \mathrm{mM}$ for BP-EGTA acid. After these concentrations, any change was not observed in the absorption curve.

The free calcium concentrations were calculated from the equation

$$
\left[\mathrm{Ca}^{2+}\right]_{\mathrm{F}}=K_{\mathrm{d}}\left(A_{\text {int }}-A_{\min }\right) /\left(A_{\max }-A_{\text {int }}\right)
$$

where $K_{\mathrm{d}}=500 \mathrm{nM}$ (fluo-3), $A_{\text {int }}=$ absorbance of chelator at setted $\mathrm{Ca}^{2+}$ concentration, $A_{\min }=$ absorbance of chelator without $\mathrm{Ca}^{2+}$, and $A_{\max }=$ absorbance of chelator with excess $\mathrm{Ca}^{2+}$.

Dissociated Cultured Neurons, Electrophysiology, and Two-Photon Uncaging. Cerebral cortices from male C57BL/6 mouse brains (E17.5) with $0.15 \%$ trypsin in ethylenediaminetetraacetic acid (Invitrogen, Carlsbad, CA, USA) and DNase I ( $\left.30 \mathrm{mg} \mathrm{mL}^{-1}\right)$ were used. The cells were plated on laminin- and poly-D-lysine-coated cover glasses with a density of $1.7 \times 10^{5}$ cells per square centimeter. The neurons 
were maintained in a serum-free medium (Neurobasal Medium; Invitrogen) supplemented with $1 \%$ GlutaMAX and 2\% B-27 supplement (Invitrogen). For electrophysiological experiments, an extracellular solution was based on SolA containing $10 \mathrm{mM} \mathrm{CaCl}, 100 \mathrm{mM}$ cyclothiazide, $50 \mathrm{mM}$ picrotoxin, and $320 \mathrm{nM}$ Na-pyruvate, at $\mathrm{pH}$ 7.4. The cultured cells were first loaded with the compound $2 \mathrm{a}(100 \mu \mathrm{M})$ for 40 min in a solution containing CrEL (0.03\%, Invitrogen) and bovine serum albumin $(5 \%)$ in SolA, followed by washing with SolA for $20 \mathrm{~min}$ at $35^{\circ} \mathrm{C}$. The postsynaptic cells (DIV 10-15) were whole-cell-clamped (holding potential $=-70 \mathrm{mV}$ ) and perfused with intracellular solution (in mM: CsCl 140, Hepes 10, MgATP 4, $\mathrm{Na}_{2}$ GTP 0.3, $\mathrm{Na}_{2}$-phosphocreatine 10, Alexa-594 $0.025, \mathrm{pH}=7.25$ with $\mathrm{CsOH})$. Electrical stimulation of $70 \mu \mathrm{A}$ amplitude was applied, at $100-150 \mu \mathrm{m}$ from the dendrites.

Two-Photon Excitation Imaging and Uncaging. The cultured neurons were placed on an inverted laser-scanning microscope (FV1000 and IX81; Olympus Corporation, Tokyo, Japan) equipped with a water-immersion objective lens (UPlanApo60xW/IR; N.A. 1.2; Olympus Corporation) and a femtosecond laser (Mai Tai; Spectra Physics Inc., Mountain View, CA, USA). Tunable wavelengths were set at 950 and 720 $\mathrm{nm}$ for imaging and uncaging, respectively.

\section{ASSOCIATED CONTENT}

\section{S Supporting Information}

The Supporting Information is available free of charge on the ACS Publications website at DOI: 10.1021/acsomega.6b00119.

Experimental procedures and compound characterization (PDF)

\section{AUTHOR INFORMATION}

\section{Corresponding Authors}

*E-mail: mabe@hiroshima-u.ac.jp (M.A.).

*E-mail: hkasai@m.u-tokyo.ac.jp (H.K.).

\section{Notes}

The authors declare no competing financial interest.

\section{ACKNOWLEDGMENTS}

NMR and MS measurements were performed at N-BARD, Hiroshima University. This work was supported by a Grant-inAid for Science Research on Innovative Areas "StimuliResponsive Chemical Species (No. 2408)” (JSPS KAKENHI Grant Number JP24109008).

\section{REFERENCES}

(1) Ellis-Davies, G. C. R. Neurobiology with caged calcium. Chem. Rev. 2008, 108, 1603-1613.

(2) Crowe, S. E.; Kantevari, S.; Ellis-Davies, G. C. R. Photochemically initiated intracellular astrocytic calcium waves in living mice using twophoton uncaging of $\mathrm{IP}_{3}$. ACS Chem. Neurosci. 2010, 1, 575-585.

(3) Zucker, R. In Calcium in Living Cells, Methods in Cell Biology; Whitaker, M., Ed.; Elsevier, 2010; Vol. 99, Chapter 2.

(4) Ellis-Davies, G. C.; Kaplan, J. H. Nitrophenyl-EGTA, a photolabile chelator that selectively binds $\mathrm{Ca}^{2+}$ with high affinity and releases it rapidly upon photolysis. Proc. Natl. Acad. Sci. U.S.A. 1994, 91, 187-191.

(5) Momotake, A.; Lindegger, N.; Niggli, E.; Barsotti, R. J.; EllisDavies, G. C. R. The nitrodibenzofuran chromophore: A new caging group for ultra-efficient photolysis in living cells. Nat. Methods 2006, 3, $35-40$.

(6) Brieke, C.; Rohrbach, F.; Gottschalk, A.; Mayer, G.; Heckel, A. Light-controlled tools. Angew. Chem., Int. Ed. 2012, 51, 8446-8476.
(7) Bort, G.; Gallavardin, T.; Ogden, D.; Dalko, P. I. From onephoton to two-photon probes: "Caged" compounds, actuators, and photoswitches. Angew. Chem., Int. Ed. 2013, 52, 4526-4537.

(8) Kim, H. M.; Cho, B. R. Small molecule two-photon probes for bioimaging applications. Chem. Rev. 2015, 115, 5014-5055.

(9) Klán, P.; Šolomek, T.; Bochet, C. G.; Blanc, A.; Givens, R.; Rubina, M.; Popik, V.; Kostikov, A.; Wirz, J. Photoremovable protecting groups in chemistry and biology: Reaction mechanisms and efficacy. Chem. Rev. 2013, 113, 119-191.

(10) Tsien, R. Y.; Zucker, R. S. Control of cytoplasmic calcium with photolabile tetracarboxylate 2-nitrobenzhydrol chelators. Biophys. J. 1986, 50, 843-853.

(11) Cui, J.; Gropeanu, R. A.; Stevens, D. R.; Rettig, J.; del Campo, A. New photolabile BAPTA-based $\mathrm{Ca}^{2+}$ cages with improved photorelease. J. Am. Chem. Soc. 2012, 134, 7733-7740.

(12) Amatrudo, J. M.; Olson, J. P.; Lur, G.; Chiu, C. Q.; Higley, M. J.; Ellis-Davies, G. C. R. Wavelength-selective one- and two-photon uncaging of GABA. ACS Chem. Neurosci. 2014, 5, 64-70.

(13) Donato, L.; Mourot, A.; Davenport, C. M.; Herbivo, C.; Warther, D.; Léonard, J.; Bolze, F.; Nicoud, J.-F.; Kramer, R. H.; Goeldner, M.; Specht, A. Water-soluble, donor-acceptor biphenyl derivatives in the 2-(o-nitrophenyl)propyl series: Highly efficient twophoton uncaging of the neurotransmitter $\gamma$-aminobutyric acid at $\lambda=$ 800 nm. Angew. Chem., Int. Ed. 2012, 51, 1840-1843.

(14) Svoboda, K.; Yasuda, R. Principles of two-photon excitation microscopy and its applications to neuroscience. Neuron 2006, 50, $823-839$.

(15) Ellis-Davies, G. C. R. Caged compounds: Photorelease technology for control of cellular chemistry and physiology. Nat. Methods 2007, 4, 619-628.

(16) Specht, A.; Bolze, F.; Omran, Z.; Nicoud, J.-F.; Goeldner, M. Photochemical tools to study dynamic biological processes. HFSP J. 2009, 3, 255-264.

(17) Pawlicki, M.; Collins, H. A.; Denning, R. G.; Anderson, H. L. Two-photon absorption and the design of two-photon dyes. Angew. Chem., Int. Ed. 2009, 48, 3244-3266.

(18) Matsuzaki, M.; Ellis-Davies, G. C. R.; Nemoto, T.; Miyashita, Y.; Iino, M.; Kasai, H. Dendritic spine geometry is critical for AMPA receptor expression in hippocampal CA1 pyramidal neurons. Nat. Neurosci. 2001, 4, 1086-1092.

(19) Ellis-Davies, G. C. R. Two-photon microscopy for chemical neuroscience. ACS Chem. Neurosci. 2011, 2, 185-197.

(20) Olson, J. P.; Kwon, H.-B.; Takasaki, K. T.; Chiu, C. Q.; Higley, M. J.; Sabatini, B. L.; Ellis-Davies, G. C. R. Optically selective twophoton uncaging of glutamate at $900 \mathrm{~nm}$. J. Am. Chem. Soc. 2013, 135, 5954-5957.

(21) Boinapally, S.; Huang, B.; Abe, M.; Katan, C.; Noguchi, J.; Watanabe, S.; Kasai, H.; Xue, B.; Kobayashi, T. Caged glutamates with $\pi$-extended 1,2-dihydronaphthalene chromophore: Design, synthesis, two-photon absorption property, and photochemical reactivity. J. Org. Chem. 2014, 79, 7822-7830.

(22) Šolomek, T.; Wirz, J.; Klán, P. Searching for improved photoreleasing abilities of organic molecules. Acc. Chem. Res. 2015, 48, 3064-3072.

(23) Palao, E.; Slanina, T.; Muchová, L.; Šolomek, T.; Vítek, L.; Klán, P. Transition-metal-free CO-releasing BODIPY derivatives activatable by visible to NIR light as promising bioactive molecules. J. Am. Chem. Soc. 2016, 138, 126-133.

(24) Ciuciu, A. I.; Korzycka, K. A.; Lewis, W. J. M.; Bennett, P. M.; Anderson, H. L.; Flamigni, L. Model dyads for 2PA uncaging of a protecting group via photoinduced electron transfer. Phys. Chem. Chem. Phys. 2015, 17, 6554-6564.

(25) Mahmoodi, M. M.; Abate-Pella, D.; Pundsack, T. J.; Palsuledesai, C. C.; Goff, P. C.; Blank, D. A.; Distefano, M. D. Nitrodibenzofuran: A one- and two-photon sensitive protecting group that is superior to brominated hydroxycoumarin for thiol caging in peptides. J. Am. Chem. Soc. 2016, 138, 5848-5859.

(26) Chen, Z.; Zhou, L.; Bing, W.; Zhang, Z.; Li, Z.; Ren, J.; Qu, X. Light controlled reversible inversion of nanophosphor-stabilized 
pickering emulsions for biphasic enantioselective biocatalysis. J. Am. Chem. Soc. 2014, 136, 7498-7504.

(27) Sedlmeier, A.; Gorris, H. H. Surface modification and characterization of photon-upconverting nanoparticles for bioanalytical applications. Chem. Soc. Rev. 2015, 44, 1526-1560.

(28) Chen, G.; Qiu, H.; Prasad, P. N.; Chen, X. Upconversion nanoparticles: Design, nanochemistry, and applications in theranostics. Chem. Rev. 2014, 114, 5161-5214.

(29) Guo, S.; Xie, X.; Huang, L.; Huang, W. Sensitive water probing through nonlinear photon upconversion of lanthanide-doped nanoparticles. ACS Appl. Mater. Interfaces 2016, 8, 847-853.

(30) Huang, P.; Zheng, W.; Zhou, S.; Tu, D.; Chen, Z.; Zhu, H.; Li, R.; Ma, E.; Huang, M.; Chen, X. Lanthanide-doped $\mathrm{LiLuF}_{4}$ upconversion nanoprobes for the detection of disease biomarkers. Angew. Chem., Int. Ed. 2014, 53, 1252-1257.

(31) Wong, H.-T.; Tsang, M.-K.; Chan, C.-F.; Wong, K.-L.; Fei, B.; Hao, J. In vitro cell imaging using multifunctional small sized $\mathrm{KGdF}_{4}$ : $\mathrm{Yb}^{3+}, \mathrm{Er}^{3+}$ upconverting nanoparticles synthesized by a one-pot solvothermal process. Nanoscale 2013, 5, 3465-3473.

(32) Yang, Y.; Shao, Q.; Deng, R.; Wang, C.; Teng, X.; Cheng, K.; Cheng, Z.; Huang, L.; Liu, Z.; Liu, X.; Xing, B. In Vitro and In Vivo Uncaging and Bioluminescence Imaging by Using Photocaged Upconversion Nanoparticles. Angew. Chem., Int. Ed. 2012, 51, 31253129.

(33) Göppert-Mayer, M. Elementary processes with two quantum jumps. Ann. Phys. 1931, 9, 272-294.

(34) Kiskin, N. I.; Chillingworth, R.; McCray, J. A.; Piston, D.; Ogden, D. The efficiency of two-photon photolysis of a "caged" fluorophore, $o-1-(2$-nitrophenyl)ethylpyranine, in relation to photodamage of synaptic terminals. Eur. Biophys. J. 2002, 30, 588-604.

(35) Miyaura, N.; Yanagi, T.; Suzuki, A. The palladium-catalyzed cross-coupling reaction of phenylboronic acid with halogens in the presence of bases. Synth. Commun. 1981, 11, 513-519.

(36) Ullah, N. Synthesis of 6-piperazinyl-3,4-dihydroquinazolin2(1H)-ones. Asian J. Chem. 2014, 26, 2031-2036.

(37) Lupattelli, P.; Bonini, C.; Caruso, L.; Gambacorta, A. Single route to chiral syn- and anti-2-amino-1,2-diphenylethanols via a new stereodivergent opening of trans-1,2-diphenyloxirane. J. Org. Chem. 2003, 68, 3360-3362.

(38) Hou, J.-L.; Jia, M.-X.; Jiang, X.-K.; Li, Z.-T.; Chen, G.-J. Solvophobically-driven oligo(ethylene glycol) helical foldamers. Synthesis, characterization, and complexation with ethane-1,2-diaminium. J. Org. Chem. 2004, 69, 6228-6237.

(39) Colombano, G.; Travelli, C.; Galli, U.; Caldarelli, A.; Chini, M. G.; Canonico, P. L.; Sorba, G.; Bifulco, G.; Tron, G. C.; Genazzani, A. A. A novel potent nicotinamide phosphoribosyltransferase inhibitor synthesized via click chemistry. J. Med. Chem. 2010, 53, 616-623.

(40) Shan, M.; Carlson, K. E.; Bujotzek, A.; Wellner, A.; Gust, R.; Weber, M.; Katzenellenbogen, J. A.; Haag, R. Nonsteroidal bivalent estrogen ligands: An application of the bivalent concept to the estrogen receptor. ACS Chem. Biol. 2013, 8, 707-715.

(41) Gould, I. R.; Lenhard, J. R.; Farid, S. A curve-crossing model for oxidative decarboxylation. Kinetics of anilino carboxylate fragmentations. J. Phys. Chem. A 2004, 108, 10949-10956.

(42) Komori, N.; Jakkampudi, S.; Motoishi, R.; Abe, M.; Kamada, K.; Furukawa, K.; Katan, C.; Sawada, W.; Takahashi, N.; Kasai, H.; Xue, B.; Kobayashi, T. Design and synthesis of a new chromophore, 2-(4nitrophenyl)benzofuran, for two-photon uncaging using near-IR light. Chem. Commun. 2016, 52, 331-334.

(43) Montalti, M.; Credi, A.; Prodi, L.; Gandolfi, M. T. Handbook of Photochemistry, 3rd ed.; CRC Press: Boca Raton, FL, 2006; pp 601604.

(44) Ellis-Davies, G. C. R; Barsotti, R. J. Tuning caged calcium: Photolabile analogues of EGTA with improved optical and chelation properties. Cell Calcium 2006, 39, 75-83.

(45) Agarwal, H. K.; Janicek, R.; Chi, S.-H.; Perry, J. W.; Niggli, E.; Ellis-Davies, G. C. R. Calcium uncaging with visible light. J. Am. Chem. Soc. 2016, 138, 3687-3693. 